\title{
1 \\ THE OPERATION AND CALIBRATION OF THE ELECTRON MICROSCOPE
}




\section{Philips Technical Library}

Monographs in Practical Electron Microscopy in Materials Science

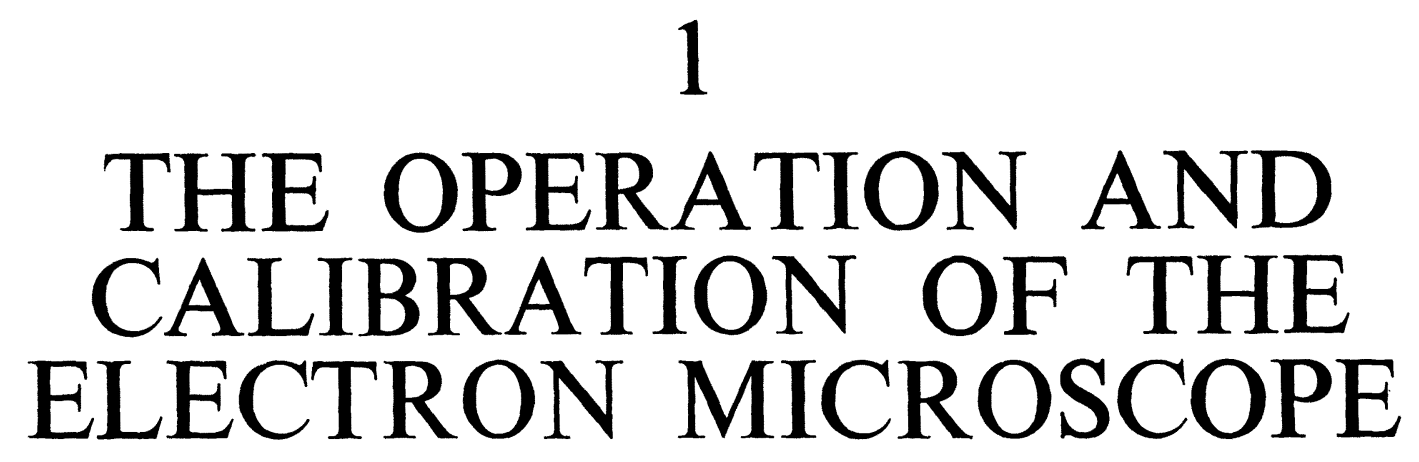

\section{J. W. EDINGTON}

Department of Metallurgy and Materials Science, University of Cambridge, Cambridge, England 
ISBN 978-1-349-02576-3 ISBN 978-1-349-02574-9 (eBook)

DOI 10.1007/978-1-349-02574-9

(C) N.V. Philips' Gloeilampenfabrieken, Eindhoven, 1974

Reprint of the original edition 1974

All rights reserved. No part of this publication

may be reproduced or transmitted, in any form

or by any means, without permission

SBN 333181336

First published 1974 by

THE MACMILLAN PRESS LTD

London and Basingstoke

Associated companies in New York, Melbourne,

Dublin, Johannesburg and Madras

\section{PHILIPS}

Trademarks of Philips' Gloeilampenfabrieken

Filmset at The Universities Press, Belfast, Northern Ireland 


\section{PREFACE}

This is the first of a series of monographs on electron microscopy aimed at users of the equipment. They are written both as texts and sources of reference emphasising the applications of electron microscopy to the characterisation of materials. The flexible monograph format will enable both the student and the professional scientist to extract the required information easily. In this context the series should be useful in specialist undergraduate and postgraduate lecture courses and as an introduction to the technique for professional scientists.

In some places the author has referred the reader to material appearing in other monographs in this series. The following three monographs are in preparation:

2-Electron Diffraction in the Electron Microscope,

3-Interpretation of Transmission Electron Micrographs and

4-Typical Electron Microscope Investigations.

Subsequent monographs in the series will cover quantitative metallography, together with aspects of design of electron microscopes. 


\section{CONTENTS}

\section{Preface}

1.1 INTRODUCTION 1

1.2 LENS DEFECTS 1

1.3 RESOLUTION 2

1.4 IMPORTANT ASPECTS OF MICROSCOPE OPERATION AND ALIGNMENT 4

1.4.1 Alignment of the Objective Lens Axis 4

1.4.2 Objective Astigmatism Correction 5

$\begin{array}{ll}\text { 1.4.3 Illumination Conditions } & 7\end{array}$

1.4.4 Axis-centred Specimen Tilt

1.5 THE FORMATION OF DIFFRACTION PATTERNS AND IMAGES

1.5.1 Selected Area Diffraction

1.5.2 Bright and Dark Field Images 10

1.5.3 Weak Beam Images 12

1.5.4 Multiple Dark Field Images 13

$\begin{array}{ll}\text { 1.5.5 Phase Contrast Images } & 14\end{array}$

$\begin{array}{llr}1.6 & \text { STEREO MICROSCOPY } & 18\end{array}$

1.7 MAGNETIC SPECIMENS

1.7.1 Magnetic Correction 18

1.7.2 Lorentz Microscopy 19

1.8 BEAM-SENSITIVE MATERIALS 19

1.9 LOW ANGLE DIFFRACTION 21

1.10 ANALYSIS OF PLATES 21

1.11 CALIBRATION OF THE MICROSCOPE

1.11.1 Image Magnification $\quad 22$

$\begin{array}{lll}\text { 1.11.1.1 Diffraction grating replicas } & 22\end{array}$

1.11.1.2 Direct lattice images 22

1.11.2 Diffraction Pattern Magnification 23

1.11.3 Image-diffraction Pattern Rotation 23

1.11.4 Errors in Use of Permanent Calibrations 24

1.11.5 Additional Measurements 25

$\begin{array}{ll}\text { 1.11.5.1 Accelerating voltage } & 26\end{array}$

$\begin{array}{lll}\text { 1.11.5.2 Specimen drift rate } & 26\end{array}$

$\begin{array}{lll}\text { 1.11.5.3 Specimen contamination rate } & 26\end{array}$

1.11.5.4 The position of the specimen tilt axis and sense of tilt 26

1.11.5.5 Focal increments of the objective lens 26

1.11.5.6 Beam current 26

1.12 RESOLUTION TESTS 27

References

APPENDIX 12. PREPARATION OF HIGH-RESOLUTION TEST SPECIMENS 31

$\begin{array}{lll}\text { A12.1 Single-crystal (100) Gold Films } & 31\end{array}$

A12.2 Partially Graphitised Carbon Black 31

A12.3 Replicas for Point-to-point resolution tests 31

Appendix 12: References 33

APPENDIX 13. HOLEY CARBON REPLICAS

Appendix 13: References 34 